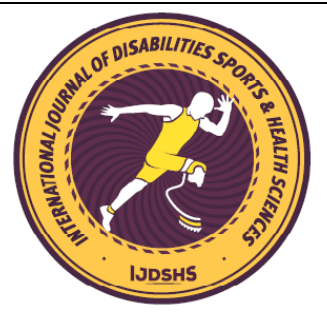

e-ISSN: 2645-9094

RESEARCH ARTICLE

\title{
High School Teachers' Burnout Levels
}

\author{
Tülay YURTTAŞ ${ }^{* 1}$ iD and Muharrerm KOKLU ${ }^{\text {(iD }}$ \\ ${ }^{1}$ Istanbul Refia övüç Maturation Institute, İstanbul,Turkey \\ ${ }^{2}$ İstanbul Okan University. Faculty of Education, Department of Education Sciences, Istanbul, Turkey \\ *Corresponding author: koklu8@ hotmail.com
}

\begin{abstract}
The purpose of this study is to determine the burnout levels of teachers according to the perceptions of teachers working in public high schools, and to reveal whether the perceptions of teachers differ significantly according to some personal characteristics of teachers and the characteristics of the school. The research is a study in general survey model. The study universe of the research, in the 2019-2020 academic year, the province of Istanbul; While the 2983 permanent high school teachers working in the state high schools in Beşiktaş, Beyoğlu, Şişli and Kağıthane districts were formed, the sample was made up of 358 teachers. "Maslach Burnout Inventory-Educator Form" was used as the data collection tool of the study. As a result of the research; from the lower dimensions of burnout. In the emotional exhaustion sub-dimension; It has been determined that teachers are rarely (sometimes very close to their level, $\overline{\mathbf{x}}=1.58 \pm 0.77$ ) burnout. Teachers' perceptions show a statistically significant difference according to gender, professional seniority, and branch variables ( $\mathrm{p}>0.05)$. In the desensitization sub-dimension; It turns out that teachers rarely show burnout $(\overline{\mathbf{X}}=0.82 \pm 0.65)$. Teacher perceptions show a statistically significant difference according to the variables of professional seniority, school type, number of students ( $\mathrm{p}>0.05$ ). In the personal success sub-dimension; It was determined that teachers were rarely in burnout $(\overline{\mathbf{X}}=2.75 \pm 0.54)$. Teachers' perceptions show a statistically significant difference according to number of children, and professional seniority variables $(\mathrm{p}>0.05)$.
\end{abstract}

\section{Keywords}

Burnout, High School Teachers, High School Teachers' Burnout

\section{INTRODUCTION}

The definition of the concept of burnout, which fundamentally affects the life of society, was first made by Bradley (1969) and then by Herbert Freudenberger, an American psychologist, in 1974. Although different definitions have been made in the future, the most well-known name among researchers about burnout is Christina Maslach, who developed the Maslach Burnout Inventory (Izgar, 2001; Tansel, 2015; Girgin, 1995). The increase in the workload of the individual and its continuousness cause emotional burnout. Since burnout causes individuals to feel helpless, exhausted, insoluble, and self-closing, it includes more negativity than stress (Girgin, 2010).

Burnout syndrome is seen in all areas of work, however, schools are among the most densely experienced places (Kabaklı Çimen and Karaboğa, 2015). Although teachers can be influenced by what they experience in other professions, they do a job that should not reflect the problems they encounter in their business or private life, especially to the students while performing their profession. Many reasons such as crowded classrooms, insufficient personal rights, lack of opportunities to improve themselves increase the risk of teachers' burnout syndrome 
and this affects the quality of education (Akçamete et al., 2001). In addition, job requirements, many different activities in the school environment, discipline problems in the classroom, bureaucracy, lack of support, workload, time pressure, and lack of benefits are among various factors related to teachers' professional stress (Mearns and Chain, 2003).

The fact that high school teachers coincide with the adolescence period of the students requires them to support their physical, emotional and cognitive development quickly. For this reason, it is very important for teachers to have motivation in their work, as well as for their students (Elbadi, 2019). Unhappy and anxious teachers cannot behave tolerant and supportive towards their students, and they are emotionally inadequate (Girgin, 1995). Under normal conditions, there are different situations that affect the burnout of high school teachers. In recent years, Many factors such as the high school curricula being far from scientific facts and contemporary realities, inequalities between permanent and paid teachers, insufficient number of schools and classrooms, crowded class sizes, education provided in education faculties at a level that cannot meet today's needs, insufficient personal rights of teachers, lack of physical capacity of schools, negativity created by dual education increase the burnout of high school teachers (Milliyet, 2018).

Through this research, it was aimed to determine the burnout levels of teachers working in state high schools in Beşiktaş, Beyoğlu, Şişli and Kağıthane districts of Istanbul and to develop solutions for teachers' levels of burnout.

\section{Purpose of the research}

The aim of this study is to determine the algorithms of teachers working in public high schools according to their perceptions on burnout dimensions, to show and reveal that some of the teachers' perceptions are personalized and the school is not reported.

In order to achieve this goal, answers to the following questions were sought:

1. According to teachers' perceptions, what is the level of burnout of teachers in terms of emotional exhaustion, depersonalization and personal accomplishment?

2.Teachers' perception levels of burnout dimensions, does it differ significantly according to their
a) their sex,
b) their marital status,
c) their professional seniority,
d) the type of school they work in,
e) its branches,
f) year of study at school,
g) the number of students in the classes they teach?

\section{The Importance of Research}

With this research, it was tried to determine the burnout levels of teachers working in high schools. In the light of the findings obtained at the end of the study, it is expected that high school administrators and higher levels officials will take measures to minimize teachers 'burnout and thus contribute to teachers' having higher quality instructional behavior.

\section{MATERIALS AND METHODS}

Research, Istanbul province; It is a research in general screening model that aims to determine the burnout levels of permanent teachers working in state high schools in Beşiktaş, Beyoğlu, Şişli and Kağıthane districts.For the research, Istanbul Okan University Ethics Committee unanimously decided that it is ethically appropriate with the decision number 21 at the meeting numbered 117 on 08.01.2020.

\section{Participants}

The study universe of the study consisted of 2983 permanent teachers working in state high schools in the districts of Beşiktaş, Beyoğlu, Şişli and Kağıthane in the 2019-2020 academic year under the Ministry of National Education of Rurkish Republic. They are close to each other as a working universe; Districts of Beyoğlu, Beşiktaş, Kağıthane, Şişli have been determined. The sample consisted of 358 teachers working in high schools in these districts and voluntarily filling in the measurement tool.

\section{Data Collection Tool}

The questionnaire in the first part of the scale used to obtain research data was organized to reveal personal characteristics and school characteristics. The Personal Information Form prepared for this purpose was prepared to determine the demographic variables of high school teachers and consists of 11 questions. These questions are gender, marital status, age, number of children, professional seniority, type of high school, branch, number of years worked in the 
institution, the average number of students in the classes taught and the last educational institution completed. In the second part of the scale; The Maslach Burnout Inventory developed by Maslach and Jackson was adapted to educators by Maslach, Jackson and Schwab with some modifications, and the "Maslach Burnout Inventory-Educator Form" adapted into Turkish by Ince and Şahin (2015) was used.

In İnce and Şahin's study (2015), the Cronbach Alpha coefficient was determined as 0.88 in the emotional exhaustion dimension, 0.78 in the depersonalization dimension, and 0.74 in the personal accomplishment dimension. The Cronbach Alpha values obtained in our study, in which five options were used, were determined as 0.73 in the emotional exhaustion dimension, 0.69 in the depersonalization dimension, and 0.71 in the personal accomplishment dimension. Points equivalents of the options vary between 0 and 4 . Factor loadings (CFA), CFA Model Goodness of Fit Index results, Reliability Analysis results were also recalculated (Yurttaş, 2020).

\section{Statistical Analyses}

The analysis of the research data was made with the SPSS 22 program. The arithmetic mean was used to determine the burnout levels of the participants. While examining whether the perceptions differ significantly according to the variables, for two variables; if the group showed normal distribution, the t-test was used for independent groups, and the Mann Whitney-U test was used if the group did not show normal distribution. In cases where the group showed homogeneity, t-Test, ANOVA and LSD test were used. The following ranges were used in the dimension of emotional exhaustion and depersonalization in the comments made according to the arithmetic mean: Never for the range of 0000.80, "Rarely" for 0.81-1.60, "Sometimes" for 1.61-2.40, "Most of the time" for 2.41-3.20, "Always" expressions are used for between 3.214.00. The personal success dimension is inversely related. As the score increases, burnout decreases. Therefore, between 0-0.80 always, between 0.811.60 most often, between1.61-2.40 sometimes, between 2.41-3.20 rarely, 3.21-4.00 never shows.

\section{RESULTS}

According to the perceptions of teachers, burnout levels are based on emotional, depersonalization and personal accomplishment dimensions.

Teachers' perceptions of the emotional exhaustion dimension $(\bar{x}=1.58 \pm 0.77)$ are at the level of "rarely". Teachers rarely perceive emotional exhaustion. Teachers, with the lowest average $(\bar{x}=0.94 \pm 0.95)$ in the item "Working with students makes me very stressful", with the highest average $(\bar{x}=2.28 \pm 1.04)$ "I feel exhausted when I finish the day at school. They reported perception in the item "I feel".

Teachers' perceptions about the depersonalization dimension $(\bar{x}=0.82 \pm 0.65)$ are at the level of "rarely". Teachers "rarely" perceive depersonalization. Teachers, with the lowest average $(\bar{x}=0.64 \pm 0.82)$ in the item "I don't really care what happens to some students", and the highest average $(\bar{x}=1.09 \pm 1.04)$ "I think teaching makes me stiff emotionally. They reported perception in the article".

Teachers' perceptions of personal achievement $(\bar{x}=2.75 \pm 0.54)$ are at the level of "rarely". Teachers rarely perceive emotional exhaustion. Teachers, with the lowest average $(\bar{x}=2.30 \pm 0.99)$ in the item "I feel very fit", and the highest average $(\bar{x}=3.09 \pm 0.7)$ "I can easily understand how my students feel about a topic They reported perception in the article" (Table 1).

The perception levels of teachers regarding the dimensions of burnout were examined in terms of gender, marital status, professional seniority, type of high school, branch, year of working in the institution, average number of students in the classes taught, and the last educational institution variables.

\section{Findings of Burnout Regarding High School Teachers by Gender Variable}

The level of teachers' perception of burnout according to their gender, Depersonalization $(\mathrm{t}=1.70 ; \quad \mathrm{p}=0.09 ; \quad \mathrm{sd}: 2 / 356)$ and Personal Achievement ( $\mathrm{t}=0.63 ; \mathrm{p}=0.53 ; \mathrm{df}: 2 / 356$ ) does not differ in size. It shows a significant difference in the Emotional Exhaustion dimension $(\mathrm{t}=2.12$; $\mathrm{p}=0.035$; df:2/356). Looking at the arithmetic averages in the emotional exhaustion dimension, women $(\bar{x}=1.66)$ show more emotional exhaustion than men $(\bar{x}=1.48)$ (Table 2). 
Burnout Findings Regarding High School Teaching According to the Vocational Seniority Variable

df:4/353) and personal accomplishment ( $\mathrm{F}=5.42$; $\mathrm{p}=0.000 ;$ df:4/353), teachers' opinions about
Emotional exhaustion $(\mathrm{F}=3.45 ; \mathrm{p}=0.008$; df:4/353), depersonalization $(\mathrm{F}=4.94 ; \mathrm{p}=0.001$;

burnout differ statistically significantly according to their professional seniority (Table 3).

Table 1. Teachers' perceptions on emotional burnout, depersonalization and personal achievement dimensions

\begin{tabular}{|c|c|c|c|c|}
\hline Boyut & Items & $\mathbf{n}$ & $\overline{\mathbf{x}}$ & ss \\
\hline \multirow{10}{*}{ 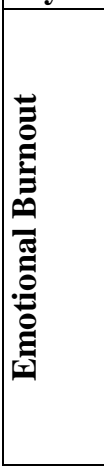 } & 1. I feel emotionally cold from teaching & 358 & 1,44 & 1,02 \\
\hline & 2. I feel exhausted when I finish the day at school & 358 & 2,28 & 1,04 \\
\hline & $\begin{array}{l}\text { 3. I feel tired when I have to get up in the morning and start a new } \\
\text { work day }\end{array}$ & 358 & 1,81 & 1,08 \\
\hline & 6. Working with students all day really challenges me & 358 & 1,60 & 1,01 \\
\hline & 8.I feel that teaching consumes me & 358 & 1,52 & 1,15 \\
\hline & 13. I think the teaching profession disappoints me & 358 & 1,38 & 1,15 \\
\hline & 14. I feel that my work load in teaching is too much & 358 & 2,24 & 1,08 \\
\hline & 16. Working with students makes me very stressed & 358 & 0,94 & 0,95 \\
\hline & 20. I feel like I cannot stand teaching any longer & 358 & 1,04 & 1,08 \\
\hline & Total & 358 & $\mathbf{1 , 5 8}$ & $\mathbf{0 , 7 7}$ \\
\hline \multirow{6}{*}{ 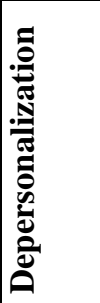 } & 5. I feel like I'm treating some students as if they were objects. & 358 & 0,80 & 0,94 \\
\hline & $\begin{array}{l}\text { 10. Since I started teaching I have become more insensitive to } \\
\text { students. }\end{array}$ & 358 & 0,88 & 0,98 \\
\hline & 11. I think being a teacher made me emotionally stiff. & 358 & 1,09 & 1,04 \\
\hline & 15. I don't really care what happens to some students & 358 & 0,64 & 0,82 \\
\hline & 22. I feel students blaming me for some of their problems. & 358 & 0,77 & 0,88 \\
\hline & Total & 358 & $\mathbf{0 , 8 2}$ & $\mathbf{0 , 6 5}$ \\
\hline \multirow{9}{*}{ 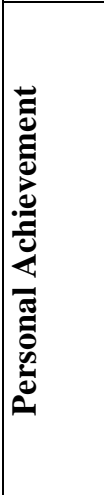 } & 4. I can e & 358 & 3,09 & 0,70 \\
\hline & 7. I am dealing with my students' problems very effectively. & 358 & 2,71 & 0,89 \\
\hline & 9. As a teacher, I feel that I am influencing students' lives positively. & 358 & 2,88 & 0,81 \\
\hline & 12. I feel very energetic & 358 & 2,30 & 0,99 \\
\hline & $\begin{array}{l}\text { 17. I can easily create a comfortable working environment with my } \\
\text { students. }\end{array}$ & 358 & 2,63 & 0,92 \\
\hline & $\begin{array}{l}\text { 18. I feel filled with enthusiasm after a work that I have done with my } \\
\text { students. }\end{array}$ & 358 & 2,97 & 0,96 \\
\hline & 19. I have achieved a lot of remarkable things in teaching & 358 & 2,77 & 0,84 \\
\hline & $\begin{array}{l}\text { 21. I deal with the emotional problems I encounter in my job quite } \\
\text { calmly. }\end{array}$ & 358 & 2,68 & 0,92 \\
\hline & Total & 358 & 2,75 & $\mathbf{0 , 5 4}$ \\
\hline
\end{tabular}

Table 2. T test measurements of teachers' perceptions of burnout according to their gender

\begin{tabular}{llcccccc}
\hline Dimensions & Gender & $\mathbf{n}$ & $\overline{\mathbf{x}}$ & $\mathbf{s s}$ & $\mathbf{t}$ & $\mathbf{d f}$ & $\mathbf{p}$ \\
\hline \multirow{2}{*}{$\begin{array}{l}\text { Emotional } \\
\text { Burnout }\end{array}$} & Female & 213 & 1,66 & 0,75 & 2,117 & 356 & 0,035 \\
\cline { 2 - 7 } Desensitization & Male & 145 & 1,48 & 0,78 & & & \\
\cline { 2 - 7 } & Female & 213 & 0,77 & 0,62 & 1,702 & 356 & 0.09 \\
\hline \multirow{2}{*}{$\begin{array}{l}\text { Personal } \\
\text { Success }\end{array}$} & Female & 213 & 2,74 & 0,54 & 0,63 & 356 & 0.53 \\
\cline { 2 - 6 } & Male & 145 & 2,78 & 0,55 & & & \\
\hline
\end{tabular}

According to the results of the LSD test conducted to determine the source of the difference, in the emotional exhaustion dimension, teachers with professional seniority of 6-10 years are among those whose professional seniority is 21 years and above ( $\mathrm{I}-\mathrm{J}=0.31 ; \mathrm{p}=0.007)$; Teachers with a professional seniority of 11-15 years have higher burnout than teachers with a professional seniority of 21 years or more ( $\mathrm{I}-\mathrm{J}=0.34 ; \mathrm{p}=0.015)$.

According to LSD test results, in the depersonalization dimension, teachers with professional seniority of 6-10 years are more than 
teachers with professional seniority of 21 years or more ( $\mathrm{I}-\mathrm{J}=0.34 ; \mathrm{p}=0.000)$; Teachers with a professional seniority of 11-15 years, and those with a professional seniority of 21 years or more

According to the LSD test results, in the personal achievement dimension, teachers with professional seniority of 21 years or more, professional seniority $1-5$ years $(\mathrm{I}-\mathrm{J}=0.21$; $\mathrm{p}=0.045), 6-10$ years $(\mathrm{I}-\mathrm{J}=0.28 ; \mathrm{p}=0.000) \quad), 11-15$
$(\mathrm{I}-\mathrm{J}=0.39 ; \mathrm{p}=0.001)$; Teachers with a professional seniority of 16-20 years ar more burnout than teachers with a professional seniority of 21 years or more (I-J=0.22; $\mathrm{p}=0.011)$.

years ( $\mathrm{I}-\mathrm{J}=0.37 ; \mathrm{p}=0.000)$ and $16-20$ years (I$\mathrm{J}=0.15 ; \mathrm{p}=0.011)$. Accordingly, teachers with a seniority of 21 years or more with higher scores are less burnout than teachers with lower scores (due to reverse scoring) (Table 4).

Table 3. F (Variance) test measurements of teachers' perceptions of burnout according to their professional seniority

\begin{tabular}{|c|c|c|c|c|c|c|c|c|c|c|}
\hline \multirow{2}{*}{$\begin{array}{l}\text { Dimension } \\
\mathrm{s}\end{array}$} & \multirow{2}{*}{$\begin{array}{l}\text { Professiona } \\
\text { I Seniority }\end{array}$} & \multicolumn{9}{|c|}{ Variance Test (Anova) Results } \\
\hline & & $\mathbf{n}$ & $\overline{\mathbf{x}}$ & ss & Source & SS & df & MS & $\mathbf{F}$ & p \\
\hline \multirow{9}{*}{$\begin{array}{l}\text { Emotional } \\
\text { Burnout }\end{array}$} & 1-5 Years & 30 & 1,34 & 0,76 & intergroup & 8,006 & 4 & 2,00 & $\begin{array}{c}3,44 \\
0\end{array}$ & 0,008 \\
\hline & $6-10$ Years & 68 & 1,78 & 0,84 & In-group & 201,93 & 35 & $\frac{1}{0,57}$ & & \\
\hline & & & & & & 6 & 3 & 2 & & \\
\hline & $11-15$ & 38 & 1,82 & 0,68 & Total & 209,94 & 35 & & & \\
\hline & Years & & & & & 2 & 7 & & & \\
\hline & $16-20$ & 89 & 1,57 & 0,78 & & & & & & \\
\hline & Years & & & & & & & & & \\
\hline & $\begin{array}{l}21 \text { Years } \\
\text { and above }\end{array}$ & $\begin{array}{c}13 \\
3\end{array}$ & 1,48 & 0,71 & & & & & & \\
\hline & Total & $\begin{array}{c}35 \\
8\end{array}$ & 1,58 & 0,77 & & & & & & \\
\hline \multirow{10}{*}{$\begin{array}{l}\text { Desensitiz } \\
\text { ation }\end{array}$} & 1-5 Years & 30 & 0,76 & 0,58 & intergroup & 7,988 & 4 & $\begin{array}{c}1,99 \\
7\end{array}$ & $\begin{array}{c}4,94 \\
1\end{array}$ & $\begin{array}{c}0,001 \\
*\end{array}$ \\
\hline & 6-10 Years & 68 & 0,99 & 0,68 & In-group & 142,68 & 35 & 0,40 & & \\
\hline & & & & & & 3 & 3 & 4 & & \\
\hline & $11-15$ & 38 & 1,04 & 0,62 & Total & 150,67 & 35 & & & \\
\hline & Years & & & & & 1 & 7 & & & \\
\hline & $16-20$ & 89 & 0,87 & 0,72 & & & & & & \\
\hline & Years & & & & & & & & & \\
\hline & 21 Years & 13 & 0,65 & 0,57 & & & & & & \\
\hline & and above & 3 & & & & & & & & \\
\hline & Total & $\begin{array}{c}35 \\
8\end{array}$ & 0,82 & 0,65 & & & & & & \\
\hline \multirow{12}{*}{$\begin{array}{l}\text { Personal } \\
\text { Success }\end{array}$} & 1-5 Years & 30 & 2,6 & 0,6 & intergroup & 6,046 & 4 & 1,51 & 5,41 & \multirow{12}{*}{$\begin{array}{c}0,000 \\
*\end{array}$} \\
\hline & & & 9 & 5 & & & & 1 & 9 & \\
\hline & 6-10 Years & 68 & 2,6 & 0,5 & In-group & 98,446 & 35 & 0,27 & & \\
\hline & & & 3 & 4 & & & 3 & 9 & & \\
\hline & $11-15$ & 38 & 2,5 & 0,5 & Total & 104,49 & 35 & & & \\
\hline & Years & & 3 & 1 & & 1 & 7 & & & \\
\hline & $16-20$ & 89 & 2,7 & 0,5 & & & & & & \\
\hline & Years & & 5 & 0 & & & & & & \\
\hline & 21 Years & 13 & 2,9 & 0,5 & & & & & & \\
\hline & and above & 3 & 0 & 1 & & & & & & \\
\hline & Total & 35 & 2,7 & 0,5 & & & & & & \\
\hline & & 8 & 6 & 4 & & & & & & \\
\hline
\end{tabular}

Burnout Findings Regarding High School Teaching According to the Variable of School Type They Work

Teachers' perceptions of burnout differed in the depersonalization dimension $(F=2.97 ; p=0.020$; df:4/353) according to the type of school they work in, emotional exhaustion $(\mathrm{F}=1.67$; $\mathrm{p}=0.158$; df:4/353) and personal success $(\mathrm{F}=1.34 ; \mathrm{p}=0.253$; df:4/353) does not differ in dimensions (Table 5). 
Table 4. LSD Test measurements of teachers' views on emotional burnout, on depersonalization and on personal success sub-dimension according to their seniority status

\begin{tabular}{lcccc}
\hline Dimensions & $\begin{array}{c}\text { Professional } \\
\text { Seniority }(\mathrm{I})\end{array}$ & $\begin{array}{c}\text { Professional } \\
\text { Seniority }(\mathrm{J})\end{array}$ & $\begin{array}{c}\text { Average } \\
\text { Difference(I-J) }\end{array}$ & $\mathrm{p}$ \\
\hline Personal & 6-10 years & 21 years and above & 0,31 & 0,007 \\
\cline { 2 - 5 } Success & $11-15$ years & 21 years and above & 0,34 & 0,015 \\
\hline \multirow{3}{*}{ Desensitization } & 6-10 years & 21 years and above & 0,34 & 0,000 \\
\cline { 2 - 5 } & $11-15$ years & 21 years and above & 0,39 & 0,001 \\
\cline { 2 - 5 } & 21 years and above & 0,22 & .011 \\
\hline \multirow{3}{*}{ Personal Success } & & $1-5$ Years & 0,21 & 0,045 \\
& \multirow{2}{*}{ 21 years and above } & 6-10 Years & 0,28 & 0,000 \\
& & $11-15$ Years & 0,37 & 0,000 \\
& & $16-20$ Years & 0,15 & 0,011 \\
\hline
\end{tabular}

Table 5. F (Variance) test measurements of teachers' perceptions of burnout according to school types they work

\begin{tabular}{|c|c|c|c|c|c|c|c|c|c|c|}
\hline \multirow{2}{*}{ Dimensions } & \multirow{2}{*}{ School Types } & \multicolumn{9}{|c|}{ Variance Test (Anova) Results } \\
\hline & & $\mathbf{n}$ & $\overline{\mathbf{x}}$ & SS & source & SS & df & MS & $\mathbf{F}$ & $\mathbf{p}$ \\
\hline \multirow{6}{*}{$\begin{array}{l}\text { Emotional } \\
\text { Burnout }\end{array}$} & 1 & 88 & 1,42 & 0,68 & intergroup & 3,888 & 4 & 0,972 & 1,665 & 0,158 \\
\hline & 2. & 52 & 1,63 & 0,75 & In-group & 206,055 & 353 & 0,584 & & \\
\hline & 3 & 110 & 1,59 & 0,76 & Total & 209,942 & 357 & & & \\
\hline & 4 & 58 & 1,68 & 0,79 & & & & & & \\
\hline & 5 & 50 & 1,72 & 0,88 & & & & & & \\
\hline & Total & 358 & 1,59 & 0,77 & & & & & & \\
\hline \multirow{6}{*}{ Desensitization } & 1 & 88 & 0,64 & 0,58 & intergroup & 4,908 & 4 & 1,227 & 2,972 & $0,020 * \mathrm{~s}$ \\
\hline & 2. & 52 & 1,00 & 0,67 & In-group & 145,763 & 353 & 0,413 & & \\
\hline & 3 & 110 & 0,83 & 0,69 & Total & 150,671 & 357 & & & \\
\hline & 4 & 58 & 0,89 & 0,67 & & & & & & \\
\hline & 5 & 50 & 0,82 & 0,60 & & & & & & \\
\hline & Total & 358 & 0,82 & 0,65 & & & & & & \\
\hline \multirow{6}{*}{$\begin{array}{l}\text { Personal } \\
\text { Success }\end{array}$} & 1 & 88 & 2,88 & 0,48 & intergroup & 1,567 & 4 & 0,392 & 1,344 & 0,253 \\
\hline & 2. & 52 & 2,70 & 0,50 & In-group & 102,924 & 353 & 0,292 & & \\
\hline & 3 & 110 & 2,76 & 0,54 & Total & 104,491 & 357 & & & \\
\hline & 4 & 58 & 2,68 & 0,62 & & & & & & \\
\hline & 5 & 50 & 2,71 & 0,59 & & & & & & \\
\hline & Total & 358 & 2,76 & 0,54 & & & & & & \\
\hline
\end{tabular}

1. Project School, 2. Anatolian High School, 3. Anatolian Vocational and Technical Secondary Education Institutions, 4. MultiProgram High School, 5. Anatolian Imam Hatip high school

Table 6. LSD test measurements of teachers' perceptions on desensitization sub-dimension according to school type

\begin{tabular}{|c|c|c|c|c|}
\hline Dimensions & School Type (I) & School Type (J) & $\begin{array}{c}\text { Average } \\
\text { Difference(I-J) }\end{array}$ & $\mathrm{p}$ \\
\hline \multirow{4}{*}{ Desensitization } & Anatolian High Schools & Project Schools & 0,36 & 0,001 \\
\hline & $\begin{array}{l}\text { Anatolian Vocational and } \\
\text { Technical Secondary }\end{array}$ & Project Schools & 0,19 & 0,038 \\
\hline & Education Institutions & & & \\
\hline & $\begin{array}{l}\text { Multi-Program High } \\
\text { Schools }\end{array}$ & Project Schools & 0,25 & 0.021 \\
\hline
\end{tabular}

According to the results of the LSD test conducted to determine the source of the difference in desensitization dimension, the teachers working in Anatolian High Schools were among the teachers working in the project schools ( $\mathrm{I}-\mathrm{J}=0.36 ; \mathrm{p}=0.001$ ); The teachers working in Anatolian Vocational and Technical High Schools are among the teachers working in the project schools ( $\mathrm{I}-\mathrm{J}=0.19 ; \mathrm{p}=0.038)$; Teachers working in multi-program high schools have higher burnout than teachers working in project schools $(\mathrm{I}-\mathrm{J}=0.25$; $\mathrm{p}=0.021$ ) (Table 6). 
Findings of Burnout Regarding High School Teaching According to the Branch Variable

Table 7. F (Variance) test measurements of teachers' perceptions of burnout according to their branches

\begin{tabular}{|c|c|c|c|c|c|c|c|c|c|c|}
\hline \multirow{2}{*}{ Dimensions } & \multirow{2}{*}{ Branch } & \multicolumn{9}{|c|}{ Variance Test (Anova) Results } \\
\hline & & n & $\overline{\mathbf{x}}$ & SS & source & SS & df & MS & $\mathbf{F}$ & p \\
\hline \multirow[t]{8}{*}{$\begin{array}{l}\text { Emotional } \\
\text { Burnout }\end{array}$} & $\begin{array}{l}\text { Turkish- } \\
\text { literatue }\end{array}$ & 52 & 1,92 & 0,70 & intergroup & 9,685 & 6 & 1,614 & 2,829 & $0,011 *$ \\
\hline & $\begin{array}{l}\text { Social } \\
\text { sciences }\end{array}$ & 32 & 1,57 & 0,68 & In-group & 200,257 & 351 & 0,571 & & \\
\hline & Science & 44 & 1,49 & 0,75 & Total & 209,942 & 357 & & & \\
\hline & Maths & 42 & 1,61 & 0,81 & & & & & & \\
\hline & $\begin{array}{l}\text { Foreign } \\
\text { languages }\end{array}$ & 73 & 1,70 & 0,83 & & & & & & \\
\hline & fine Arts & 73 & 1,46 & 0,70 & & & & & & \\
\hline & others & 69 & 1,44 & 0,81 & & & & & & \\
\hline & Total & 358 & 1,59 & 0,77 & & & & & & \\
\hline \multirow[t]{8}{*}{ Desensitization } & $\begin{array}{l}\text { Turkish- } \\
\text { literatue }\end{array}$ & 52 & 1,00 & 0,69 & intergroup & 2,474 & 6 & 0,412 & 0,977 & 0,441 \\
\hline & $\begin{array}{l}\text { Social } \\
\text { sciences }\end{array}$ & 32 & 0,75 & 0,64 & In-group & 148,197 & 351 & 0,422 & & \\
\hline & Science & 44 & 0,74 & 0,61 & Total & 150,671 & 357 & & & \\
\hline & Maths & 42 & 0,79 & 0,63 & & & & & & \\
\hline & $\begin{array}{l}\text { Foreign } \\
\text { languages }\end{array}$ & 73 & 0,85 & 0,62 & & & & & & \\
\hline & fine Arts & 73 & 0,76 & 0,65 & & & & & & \\
\hline & others & 69 & 0,82 & 0,68 & & & & & & \\
\hline & Total & 358 & 0,85 & 0,65 & & & & & & \\
\hline \multirow{8}{*}{$\begin{array}{l}\text { Personal } \\
\text { Success }\end{array}$} & $\begin{array}{l}\text { Turkish- } \\
\text { literatue }\end{array}$ & 52 & 2,71 & 0,50 & intergroup & 1,826 & 6 & 0,304 & 1,041 & 0,399 \\
\hline & $\begin{array}{l}\text { Social } \\
\text { sciences }\end{array}$ & 32 & 2,74 & 0,52 & In-group & 102,665 & 351 & 0,292 & & \\
\hline & Science & 44 & 2,82 & 0,69 & Total & 104,491 & 357 & & & \\
\hline & Maths & 42 & 2,69 & 0,40 & & & & & & \\
\hline & $\begin{array}{l}\text { Foreign } \\
\text { languages }\end{array}$ & 73 & 2,62 & 0,68 & & & & & & \\
\hline & fine Arts & 73 & 2,81 & 0,49 & & & & & & \\
\hline & others & 69 & 2,82 & 0,57 & & & & & & \\
\hline & Total & 358 & 2,76 & & & & & & & \\
\hline
\end{tabular}

Teachers' perceptions of burnout do not $(\mathrm{F}=1.04 ; \mathrm{p}=0.339 ; \mathrm{df}: 6 / 351)$, but emotional differ in terms of depersonalization ( $\mathrm{F}=0.98$; depletion $(\mathrm{F}=2.83 ; \mathrm{p}=0.011$; df:6/351) (Table 7). $\mathrm{p}=0.441$; df:6/351) and personal achievement

Table 8. LSD Test Measurements According to the Branches of Teachers' Perceptions on Emotional Burnout Dimension

\begin{tabular}{|c|c|c|c|c|}
\hline Dimensions & Branch (I) & $\operatorname{Branch}(\mathrm{J})$ & Average difference(I-J) & $\mathrm{p}$ \\
\hline \multirow{6}{*}{$\begin{array}{l}\text { Emotional } \\
\text { Burnout }\end{array}$} & \multirow{6}{*}{ Turkish-literatue } & Social sciences & 0,36 & 0.037 \\
\hline & & Science & 0,43 & 0.005 \\
\hline & & maths & 0,32 & 0.044 \\
\hline & & Foreign languages & 0,23 & 0.138 \\
\hline & & Fine Arts & 0,47 & 0.001 \\
\hline & & Other & 0,49 & 0.000 \\
\hline
\end{tabular}

According to the results of the LSD test conducted to find the source of the difference, in the emotional exhaustion dimension, teachers whose branches are Turkish-literature, social studies (I-
$\mathrm{J}=0.36 ; \mathrm{p}=0.037)$, science (I-J=0.43; $\mathrm{p}=0.005)$, They scored higher than teachers of mathematics $(\mathrm{I}-\mathrm{J}=0.32 ; \mathrm{p}=0.044)$, fine arts ( $\mathrm{I}-\mathrm{J}=0.47 ; \mathrm{p}=0.001)$ and other $(\mathrm{I}-\mathrm{J}=0.49 ; \mathrm{p}=0.000)$ (Table 8$)$. 
Accordingly, teachers whose branch is TurkishLiterature see themselves more exhausted than

\section{DISCUSSION AND CONCLUSION}

Teachers' perceptions of the emotional exhaustion dimension $(\bar{x}=1.58 \pm 0.77)$ are at the level of "rarely". This finding shows that high school teachers rarely have a perception of emotional exhaustion. Teachers showed the highest perception level $(\bar{x}=2.28 \pm 1.04)$ in this dimension in the item "I feel exhausted when I finish the day at school". This means chronic fatigue and is an indicator of burnout. Kaya (2019) found that the level of emotional exhaustion ( $\bar{x}=2.84 \pm 0.49)$ was "sometimes at the level" in his research "Investigation of the Burnout Levels of Teachers Working in the Field of Special Education". This result is higher than the result found in our study. Accordingly, it can be said that the emotional burnout of high school teachers is lower than the emotional burnout of teachers working in the special education field. Çolak (2017), in his master's thesis "Investigation of the Burnout Levels of Managers and Teachers Working in Primary and Secondary Schools", found that the average burnout levels of the participants were $15.52 \pm 7.03$ in the emotional burnout sub-dimension. According to this score, the emotional exhaustion subscale of the participants is at a low level. Çolak (2017) found that the average burnout levels of the participants in his master's thesis "Investigation of the Burnout Levels of Administrators and Teachers Working in Primary and Secondary Schools" was $4.79 \pm 3.42$ in the depersonalization sub-dimension. According to this score, the depersonalization sub-dimension of the participants is low. In Çolak (2017), in his master's thesis "Investigation of the Burnout Levels of Administrators and Teachers Working in Primary and Secondary Schools", the average burnout levels of the participants are $21.33 \pm 4.04$ in the personal achievement sub-dimension. According to this score, it is seen that the participants experience moderate burnout in the personal achievement sub-dimension. Billingsley et al. (1995) compared 470 special education and regular school teachers and found that the burnout rate of teachers working in the special education field ranged from 5.8 to 7.9 percent, while this rate was 4.6 to 5.8 percent for teachers working in regular institutions. .(Akçamete et al.2001). teachers whose branches are Social Studies, Science, Mathematics, Fine Arts and others.

Kuloğlu-Aksaz (1996) compared the burnout levels of teachers working with disabled and nondisabled children using the Maslach Burnout Inventory. According to the results of this study, it was found that there was no difference between the total burnout scores of the two groups of teachers, both groups did not differ in terms of emotional exhaustion and depersonalization, but primary school teachers saw themselves more successful than teachers working with disabled children.(Akçamete et al., 2001)

Teachers' perceptions about the depersonalization dimension $(\bar{x}=0.82 \pm 0.65)$ are at the level of "rarely". This finding shows that high school teachers rarely have a sense of depersonalization. Teachers showed the highest perception level $(\bar{x}=1.09 \pm 1.04)$ in this dimension in the item "I think teaching makes me stiff emotionally".Teachers' feeling of solidification can prevent them from interacting well with students. Şanlı and Tan (2017) found that teachers' perceptions of depersonalization sub-dimension $(\bar{x}=1.87)$ were "rarely" in their study in which they analyzed their burnout levels. This result coincides with the finding obtained from our study.

Teachers' perceptions of personal achievement $(\bar{x}=2.75 \pm 0.54)$ are at the level of "rarely". Since there is an inverse relationship in this dimension, the higher the success score, the lower the level of burnout. Therefore, teachers' burnout is at the "rarely" level. Teachers showed the highest level of perception $(\bar{x}=3.09 \pm 0.7)$ in this dimension in the item "I can easily understand how my students feel about a subject". Gündüz (2006), in his study to determine the burnout levels of school administrators and teachers, found that their perceptions of personal achievement $(\bar{x}=1.20)$ were at the level of "rarely". The finding of our study coincides with Gündüz's (2006) research findings.

Teachers' perceptions do not differ according to their gender in Depersonalization and Personal Achievement dimensions. It shows a significant difference in the Emotional Exhaustion dimension $(\mathrm{t}=2.12 ; \mathrm{p}=0.035 ; \mathrm{df}: 2 / 356)$. Looking at the arithmetic averages in the emotional exhaustion dimension, women $(\bar{x}=1.66)$ show more emotional exhaustion than men $(\bar{x}=1.48)$. It can be said that 
this situation is due to the higher workload and responsibilities of women in the family, as well as their occupational workload. This finding is similar to the result obtained from the study in which Cemaloğlu and Erdemoğlu Şahin (2007) found that the level of emotional exhaustion was highest in women and the lowest in men in their study on teachers. Similarly, in the study of Maslach and Jackson (1981), a high level of emotional exhaustion was observed in women in the emotional exhaustion sub-dimension (Maslach and Jackson, 1981). In their study, Sezgin and Kilınç (2012) found that there was no gender difference in depersonalization sub-dimension, similar to our study. Karahan and Uyanık Polat (2011), in their study investigating the burnout levels of educators, determined that unlike our study, educators' views of personal achievement differ according to their gender. In a study conducted by Antoniou, Polychroni, and Vlachakis (2006) in Greece, they focused on the gender difference in occupational stress and occupational burnout among primary and high school teachers, and it was reported that female teachers have higher burnout levels than male teachers, unlike our study (Antoniou et al., 2006). In the study in which Erkul and Dalgıç (2014) examined the occupational burnout levels of vocational high school teachers in Şişli, Istanbul; While the thoughts of the participants in emotional exhaustion dimension vary according to gender, their thoughts in depersonalization and personal success sub-dimensions do not change according to gender. Therefore, in the emotional exhaustion dimension, it was determined that female teachers felt more emotional exhaustion than male teachers (Erkul and Dalgıç, 2014). This difference between male and female teachers in burnout; It is possible to attribute this to their inability to acquire or use appropriate psychological coping resources in line with the demands of the profession. Teachers may have difficulty in coping with problems that may cause them to experience burnout with the effect of their social status in their daily lives.

Teachers' perceptions of burnout according to their marital status, Emotional Exhaustion $(\mathrm{F}=0.805, \mathrm{p}=0.45, \mathrm{sd}: 2 / 355)$, Depersonalization $(\mathrm{F}=0.086, \mathrm{p}=0.91, \mathrm{sd}: 2 / 355)$ and Personal success $(\mathrm{F}=0.309, \mathrm{p}=0.27, \mathrm{sd}: 2 / 355)$ does not differ in size. In their study, Sezgin and Kılınç (2012) determined that there is a statistical difference between burnout sub-dimensions and marital status variable, similar to our study. Izgar (2001), in his research named "Burnout in School Administrators", found that the burnout levels of school principals differ significantly in the emotional exhaustion and personal achievement sub-dimensions, unlike our study, and it was found that there was no significant difference in the depersonalization sub-dimension. Similarly, Ardıç and Polatç1 (2008) found that there was no significant difference in emotional exhaustion dimensions in terms of marital status, and there was no significant difference in depersonalization and personal success dimensions. This finding is similar to the data of the study in which Bahar's (2006) study named Burnout Syndrome, An Application in Front Office Employees in Hotel Businesses, there is no significant difference in the personal success sub-dimension of married and unmarried people. Emotional exhaustion $(\mathrm{F}=3.45$; $\mathrm{p}=0.008$; sd:4/353), depersonalization $(\mathrm{F}=4.94$; $\mathrm{p}=0.001$; sd:4/353) and personal achievement $(\mathrm{F}=5.42 ; \mathrm{p}=0.000 ; \mathrm{sd}: 4 / 353)$, teachers' opinions about burnout differ statistically according to their professional seniority.

According to the results of the LSD test conducted to determine the source of the difference, in the emotional exhaustion dimension, teachers with professional seniority of 6-10 years are among those whose professional seniority is 21 years and above ( $\mathrm{I}-\mathrm{J}=0.31 ; \mathrm{p}=0.007)$; Teachers with a professional seniority of 11-15 years have higher burnout than teachers with a professional seniority of 21 years or more ( $\mathrm{I}-\mathrm{J}=0.34 ; \mathrm{p}=0.015$ ). In the depersonalization dimension, teachers with professional seniority of 6-10 years are more than teachers with professional seniority of 21 years or more ( $\mathrm{I}-\mathrm{J}=0.34 ; \mathrm{p}=0.000) ; \quad$ Teachers with a professional seniority of 11-15 years, and those with a professional seniority of 21 years or more ( $\mathrm{I}-\mathrm{J}=0.39 ; \mathrm{p}=0.001)$; Teachers with a professional seniority of 16-20 years are more burnout than teachers with a professional seniority of 21 years or more ( $\mathrm{I}-\mathrm{J}=0.22 ; \mathrm{p}=0.011)$. In the dimension of personal success, teachers with professional seniority of 21 years or more, professional seniority $1-5$ years $(\mathrm{I}-\mathrm{J}=0.21 ; \mathrm{p}=0.045), 6-10$ years $(\mathrm{I}-\mathrm{J}=0.28 ; \mathrm{p}=0.000), 11-15$ scores higher than teachers with years $(\mathrm{I}-\mathrm{J}=0.37 ; \mathrm{p}=0.000)$ and $16-20$ years $(\mathrm{I}-\mathrm{J}=0.15 ; \mathrm{p}=0.011)$. Accordingly, teachers with a seniority of 21 years or more with higher scores are less burnout than teachers with lower scores (due to reverse scoring). 
Girgin (2010), in his research, concluded that there is a significant difference between the years of seniority and emotional burnout, which supports our study. Similar to our study, Elbadi (2019) found no statistically significant difference between professional seniority and Emotional Exhaustion and personal achievement subdimensions. Soyer, Can, and Kale (2009) found in their study "Examining the job satisfaction and professional burnout levels of physical education teachers in terms of various factors", different from our research, that there is no statistically significant difference between the seniority of teachers and depersonalization and personal achievement sub-dimensions. Similarly, Sezgin and Kilıç (2012) found that there was no significant difference between teachers' professional seniority levels and their burnout levels.

Teachers' perceptions of burnout differ in depersonalization dimension $(\mathrm{F}=2.97 ; \mathrm{p}=0.020$; sd:4/353) according to the type of school they work in, while emotional exhaustion $(\mathrm{F}=1.67$; $\mathrm{p}=0.158$; sd:4/353) and personal success $(\mathrm{F}=1.34$; $\mathrm{p}=0.253$; sd:4/353) does not differ in terms of dimensions. According to the results of the LSD test conducted to determine the source of the difference in desensitization dimension, the teachers working in Anatolian High Schools were among the teachers working in the project schools ( $\mathrm{I}-\mathrm{J}=0.36 ; \mathrm{p}=0.001)$; The teachers working in Anatolian Vocational and Technical High Schools are among the teachers working in the project schools ( $\mathrm{I}-\mathrm{J}=0.19 ; \mathrm{p}=0.038)$; Teachers working in multi-program high schools have higher burnout than teachers working in project schools ( $\mathrm{I}-\mathrm{J}=0.25$; $\mathrm{p}=0.021$ ).

Şanlı and Tan (2017), in their study examining teachers 'burnout levels, found that there was no statistically significant difference between teachers' school types and Emotional Exhaustion and personal achievement subdimensions. This result is similar to our research. Dağc1 (2019) found in her study that there was no statistically significant difference between the school type variable and the burnout level subdimensions. Similar to our findings. Similar to our findings, Cemaloğlu and Erdemoğlu Şahin (2007) found a statistically significant difference between teachers' school types and depersonalization subdimension in their study to determine the professional burnout levels of teachers.
Teachers' perceptions of their burnout according to their branches, did not differ significantly in terms of depersonalization $(\mathrm{F}=0.98 ; \quad \mathrm{p}=0.441 ; \mathrm{sd}: 6 / 351)$ and personal achievement $\quad(\mathrm{F}=1.04 ; \quad \mathrm{p}=0.339 ; \quad$ sd:6/351) dimensions. shows a significant difference in the dimension of emotional exhaustion $(\mathrm{F}=2.83$; $\mathrm{p}=0.011 ; \mathrm{sd}: 6 / 351)$.

According to the results of the LSD test conducted to find the source of the difference, in the emotional exhaustion dimension, teachers whose branches are Turkish-literature, social studies ( $\mathrm{I}-\mathrm{J}=0.36 ; \mathrm{p}=0.037)$, science ( $\mathrm{I}-\mathrm{J}=0.43$; $\mathrm{p}=0.005)$, They scored higher than teachers of mathematics ( $\mathrm{I}-\mathrm{J}=0.32 ; \mathrm{p}=0.044)$, fine arts (I$\mathrm{J}=0.47 ; \mathrm{p}=0.001)$, and other $(\mathrm{I}-\mathrm{J}=0.49 ; \mathrm{p}=0.000)$. Accordingly, teachers whose branch is TurkishLiterature see themselves more exhausted than teachers whose branches are Social Studies, Science, Mathematics, Fine Arts and others.

Ersoy Y1lmaz et al. (2014) found a statistically significant difference between the branches of teachers and the Emotional Exhaustion and personal achievement sub-dimensions, similar to the findings we obtained from our study, in their study to determine teachers' burnout levels. Dağc1 (2019) found in her study that there was no statistically significant difference between the branch variable and the burnout level subdimensions. Izgar (2001) found that there is a statistically significant difference between the branches of teachers and the depersonalization sub-dimension, unlike our research.

\section{CONCLUSION}

\section{The conclusions reached according to the Sub- Problems can be listed as follows:}

Teachers' perceptions of the emotional exhaustion, depersonalization and personal success dimensions are at the level of "rarely". When the results obtained according to the sub-problems are summarized according to the dimensions: In the emotional exhaustion dimension, teachers' perceptions of burnout show statistically significant differences according to the variables of gender, professional seniority, and branch. Teacher perceptions do not show a statistically significant difference according to marital status, school type, year of study, number of students, and educational status. In the depersonalization dimension, teachers' perceptions of burnout show statistically significant differences according to the 
variables of professional seniority, school type, and number of students. Teacher perceptions do not show a statistically significant difference according to the variables of gender, marital status, branch, working year, and educational status. In the personal achievement dimension, teachers' perceptions of burnout show statistically significant differences according to professional seniority variables. Teacher perceptions do not show a statistically significant difference according to the variables of gender, marital status, school type, branch, working year, number of students, and educational status.

Conflict of interest: The authors declare no conflict of interest. No financial support was received.

\section{Ethics Statement}

The studies involving human participants were reviewed and approved by the Okan University, Scientific Research Ethics Committee (Date: 08.01.2020; Decision / Protocol number: 21/117). Written informed consent to participate in this study was provided by the patients/participants.

\section{REFERENCES}

Addis, S.R. (2006). Burnout among undergraduate athletic training students. Thesis Submitted to the Faculty of the School of Graduate Studies and Research of California University of Pennsylvania in partial fulfillment of the requirements for the degree of Master of Science.

Adigüzel, İ. (2016). The Relations Between PreSchool Teachers Classroom Management Skills And Burnout Level. Master Thesis, Recep Tayyip Erdogan University Institute of Social Sciences, Rize.

Akçamete, G., Kaner, S. and Sucuoğlu, B. (2001). Burnout job satisfaction and personality in teachers. Istanbul: Nobel Publications.

Antoniou, A.S. Polychroni, and F. Vlachakis, (2006). Gender and age differences in occupational stress and professional burnout between primary and high-school teachers in Greece. Journal of Managerial Psychology, 21(7), 682-690.

Ardıç, K. and Polatçı, S. (2008). Emotional Exhaustion: An Application To Academic
Personal. Journal of Gazi University Faculty of Economics and Administrative Sciences, 10(2), 69-96.

Bahar, E. (2006). Burnout syndrome, an application in front office employees in hotel businesses. Master Thesis. Adnan Menderes University, Institute of Social Sciences, Aydın.

Cemaloğlu, N. and Erdemoğlu Şahin, D. (2007). A Study of The Teacher's Burnout Level According To Various Variables. Kastamonu Journal of Education, 15(2), 465-484.

Çelikkaleli, Ö. (2011). Examination of burnout and Professional competencies of adult educator teachers. Mehmet Akif Ersoy Üniversity Journal of Cocial Sciences Institute, 3(4), 38-53.

Çolak, Y. (2017). Investigation of Burnout Levels of Administrators and Teachers Working in Primary and Secondary Schools. Master Thesis, Gaziantep University, Institute of Educational Sciences, Gaziantep

Dağc1, A. (2019). A mixed research on teachers' burnout level and the dimensions of burnout related to school management. Master Thesis, Maltepe University Institute of Social Sciences, Istanbul.

Dilsiz, B. (2006). Multivariate statistical analysis of the evaluation of burnout and job satisfaction levels of teachers working in secondary schools in Konya province according to regions. Master Thesis, Selcuk University, Institute of Science and Technology, Konya.

Elbadi, B. C. (2019). Examination of some demographic characteristics affecting professional burnout in mathematics teachers, Adana province example. Master Thesis, Çağ University Institute of Social Sciences, Mersin.

Erkul, A. and Dalgıç, G. (2014). Examination of vocational burnout levels of vocational high school teachers. Journal of Educational Sciences Research, 4(2), 1-18.

Ersoy Yılmaz, S. Yazıc1, N. and Yazıc1, H. (2014). Examining Burnout Levels of Teachers And Administrators Teacher. Journal of Management and Economics Studies, 24, 135-157.

Filiz, Z. (2014). Investigation of teachers' job satisfaction and burnout levels. International 
Journal of Management, Economcs and Business, 10(23), 157-171.

Freudenberger, H. J. (1974). Staff burnout. Journal of Social Issues. 30, 159-165.

Girgin, G. (1995). Analysis of the variables affecting the development of professional burnout in primary school teachers and a model proposal, Master Thesis, Dokuz Eylul University Institute of Social Sciences, Izmir.

Girgin, G. (2010) Investigation of factors affecting burnout in teachers. Electronic Journal of Social Sciences, 9(32), 32-48.

Göktepe, A.K. (2016). Burnout syndrome. Istanbul: Nesil Publishing House.

Gündüz, H. (2006). Burnout levels of administrators and teachers working in regional boarding primary schools, Diyarbakir example. Master's Thesis, Dicle University Institute of Social Sciences, Diyarbakir.

Hurşitoğlu, O. (2017). Factors affecting burnout syndrome in doctors working as research assistants and the relationship of burnout syndrome with defense styles. Specialization Thesis, Kahramanmaraş Sütçü İmam University Faculty of Medicine, Department of Mental Health and Diseases, Kahramanmaraş.

Iş1khan, V. (2016). Burnout syndrome in employees. http://www.solunum.org.tr Access Date: 01.03.2020.

Izgar, H. (2000). The reasons for burnout levels of school administrators and their examination according to some effective factors. $\mathrm{PhD}$. Thesis, Selcuk University, Institute of Social Sciences, Konya.

Izgar, H. (2001). Burnout in school administrators. Istanbul: Nobel Publication Distribution.

İnce, N.B. and Şahin, A.E. (2015). A study of adapting the Maslach Burnout InventoryTrainer Form into Turkish. Journal of Measurement and Evaluation in Education and Psychology, 6(2), 385-399.

Kabaklı Çimen, L. and Karaboğa, Y. (2015). Opinions of administrators and teachers on disciplinary problems in secondary education institutions. International Journal of Science Culture and Sport (IntJSCS), 3, 613-628

Karahan, Ş. and Uyanık Balat, G. (2011). Examination of self-efficacy perceptions and burnout levels of educators working in special education schools. Pamukkale University Journal of the Faculty of Education, 29(1), 1-14.

Karapınar, M. and Gürbüz, H. (2015). Eskişehir Osmangazi University Faculty of Economics and Administrative Sciences, 10(2), 245-267.

Maslach, C. (1993). Burnout: A multidimensional perspective. W. B. Schaufeli, C. Maslach ve T. Marek. Professional Burnout: Recent Developments in Theory and Research. Taylor and Francis: Washington, DC

Maslach, C. and Jackson, S.E. (1981). The measurement of experienced burnout. Journal of Organizational Behavior 2(2), 99-113.

Maslach, C. Jackson, S.E. and Leiter, M.P. (1996). MBI: The Maslach Burnout Inventory: Evaluating Stress. Editors: C. P. Zalaquett, R. J. Wood. A Book of Resources Publisher: The Scarecrow Press

Mearns, J. and Cain, J. E. (2003). Relationships between teachers' occupational stress and their burnout and distress: Roles of coping and negative mood regulation expectancies. Anxiety, Stress \& Coping: An International Journal, 16(1), 71-82.

Milliyet Newspaper, (2018). The minister asked, the teachers identified the problems! The list is long, 14 October 2018.

Örmen, U. (1993). An application on the feeling of burnout and managers. Master Thesis, Marmara University Institute of Social Sciences, Istanbul.

Özipek, A.K. (2006). Professional burnout level and causes of teachers working in secondary schools. Master Thesis, Trakya University Institute of Social Sciences, Edirne.

Poyraz, K. and Sürücüoğlu, H. (2015).Burnout in Primary and Secondary School Adminstrators (The Example of Kütahya City Center), Dumlupınar University Journal of Social Sciences, 44, 9-23

Sezgin, F. and Kılınç, A. Ç. (2012). The Relationship Between Professional Burnout Levels of Primary School Teachers and Organizational Citizenship Behaviors. Journal of Ahi Evran University Kirsehir Education Faculty (KEFAD), 13(3), 103127. 
Soyer, F. Can, Y. and Kale, F. (2009). Investigation of Physical Education Teachers' Job Satisfaction and Profeeional Burnout Levels in Terms of Various Factors, Niğde University Journal of Physical Education and Sport Sciences, 3(3), 259271.

Şanlı, Ö. and Tan, Ç. (2017). Analysing Of Teachers Exhaustion Level With Regards To Several Variables. The Journal of International Social Sciences , 27(2), 131142.

Tansel, B. (2015). Examining of The Burnout Level of University Students. Journal of Çukurova University Faculty of Education, 44(2), 241-262.

Tatlilıoglu, K. (2019). The concept of burnout in the context of Maslach and Jackson's burnout model. III. Taras Shevchenko International Congress On Social Sciences, Bingöl Üniversitesi, Bingöl.

Torun, A. (1995). An investigation on family structure and social support relationships. Master Thesis, Marmara University Institute of Social Sciences, Istanbul.

Tuğrul, B. and Çelik, E., (2002). Burnout in kindergarten teachers working with normal children. Pamukkale Universiy Faculty of Education Journal, 2(12), 1-11.

Yaşar Ekici, F. (2017). Evaluation of preschool teachers in terms of Professional burnout. Mus Alparslan University Journal of Social Sciences, 5(2), 425-446.

Yilmaz Toplu, N. (2012). Burnout levels of preschool and primary school teachers. Master Thesis, Adnan Menderes University Institute of Social Sciences, Aydin.

Yurttaş, T. (2020). Burnout Levels of High School Teachers. Master Thesis, Istanbul Okan
University Institute of Social Sciences, Istanbul.

How to cite this article: Yurttaş, T. and Koklu, M. (2021). High School Teachers' Burnout Levels. Int $J$ Disabil SportsHealth Sci; 4(2):100-112. https://doi.org/10.33438/ijdshs. 936549 